\title{
Antimicrobial resistance of Streptococcus spp. and Staphylococcus spp. isolated from respiratory tract of race horses in Türkiye
}

\author{
Mehmet DíRí ${ }^{1, a, ®}$, Bülent BAŞS, ${ }^{2, b}$ Ender YARSAN ${ }^{3, c}$ \\ ${ }^{1}$ General Directorate of Food and Control / Ministry of Agriculture and Forestry, 06800, Çankaya, Ankara, Türkiye; ${ }^{2}$ Ankara \\ University Faculty Veterinary Medicine / Department of Microbiology Ziraat Mah., Şehit Ömer Halisdemir Bulvarı, 06110 Altındağ, \\ Ankara, Türkiye; ${ }^{3}$ Ankara University Faculty Veterinary Medicine / Department of Pharmacology and Toxicology Ziraat Mah., Şehit \\ Ömer Halisdemir Bulvarı, 06110 Altındağ, Ankara, Türkiye \\ aORCID: 0000-0002-2971-1522; bORCID: 0000-0001-9992-8738; 'ORCID: 0000-0002-3008-9240
}

Corresponding author: mehmetdiri78@hotmail.com

Received date: 19.11.2020 - Accepted date: 03.08.2021

\begin{abstract}
As with other animal species, one of the most important challenges encountered in race horse breeding is performance and economic losses caused by infectious diseases. Antibiotics are the most important and common drugs used for protection against infectious diseases. Recently with the occurrence of antibiotic resistance, serious complications have emerged in terms of human and animal health. For this reason, to determine antibiotic resistance in bacteria, many research studies have been carried out in the world and Türkiye. However, in Türkiye no comprehensive study has yet been conducted on antibiotic resistance in race horses. Within the scope of this study, it was aimed to investigate antibacterial susceptibility and resistance in Streptococcus spp. and Staphylococcus spp. agents identified through isolation from tracheal aspiration fluid samples taken from thoroughbred horses brought to 75 . Y1l Hippodrome Hospital. Disk Diffusion and Minimum Inhibitory Concentration (MIC) tests were used to determine antibacterial susceptibility. Susceptibility profiles of identified strains against some penicillin, cephalosporin, aminoglycoside, tetracycline, rifamycin and carbapenem group antibacterial drugs were determined. Also, it has been determined that 1 Streptococcus spp. and 10 Staphylococcus spp. agents are sensitive to amoxicillin and ampicillin-sulbactam; moderately sensitive to penicillin and amikacin and resistant to trimethoprim-sulfamethoxazole, kanamycin, gentamicin, enrofloxacin and rifampin.
\end{abstract}

Keywords: Antimicrobial susceptibility, disc diffusion, minimum inhibitory concentration (MIC), Staphylococcus spp. and Streptococcus spp., thoroughbreds.

\section{Türkiye'deki yarış atlarının solunum yollarından izole edilen Streptococcus spp. ve Staphylococcus spp. etkenlerinin antibiyotik direnci}

Özet: Diğer hayvan türlerinde olduğu gibi yarış atı yetiştiriciliğinde karşılaşılan en önemli zorluklardan birisi enfeksiyöz hastalıklardan kaynaklanan performans ve ekonomik kayıplardır. Antibiyotikler, enfeksiyöz hastalıklara karşı mücadelede kullanılan en önemli ve yaygın ilaçlardır. Son zamanlarda antibiyotik direncinin oluşması ile birlikte insan ve hayvan sağlığı açısından ciddi komplikasyonlar ortaya çıkarmaktadır. Bu nedenle, bakterilerde oluşan antibiyotik direncinin tespiti amacıyla dünyada ve Türkiye'de yapılmış bir çok araştırma bulunmaktadır. Ancak Türkiye'de, yarış atlarında antibiyotik direnci üzerine kapsamlı bir çalışmaya rastlanılmamıştır. Bu çalışma kapsamında 75. Yıl Hipodromu At Hastanesine getirilen safkan atlardan alınan trakeal aspirasyon sıvısı numunelerinden izole edilerek identifiye edilen Streptococcus spp. ve Staphylococcus spp. etkenlerinde antibakteriyel duyarlılık ve direncin araştırılması amaçlandı. Antibakteriyel duyarlılı̆̆ın tespitinde Disk Difuzyon ve Minimum İnhibitör Konsantrasyon (MIC) testlerinden yararlanıldı. Tespit edilen suşların bazı penisilin, sefalosporin, aminoglikozid, tetrasiklin, rifamisin ve karbapenem grubu antibakteriyel ilaçlara karşı duyarlılık profilleri çıkarıldı. 1 Streptococcus spp. ve 10 Staphylococcus spp.'nin amoksisilin ve ampisilinsulbaktam'a duyarl1; penisilin ve amikasine orta derecede duyarl1; trimetoprim-sülfametoksazol, kanamisin, gentamisin, enrofloksasin ve rifampine ise dirençli olduğu tespit edildi.

Anahtar sözcükler: Antimikrobiyel duyarl1l1k, disk difuzyon, minimum inhibitör konsantrasyon (MIC), Staphylococcus spp. ve Streptococcus spp., safkan at. 


\section{Introduction}

Today, antibiotics have an important place in the prevention and treatment of diseases, and also in increasing the productivity power in animals. Especially after 1950, the widespread use of antibiotics as growth accelerators in food additives in animals promoted the development of resistance against antibiotics $(1,2,14-16$, 22).

According to the World Health Organization (WHO) Antimicrobial Resistance Monitoring Global Report, resistance against common bacteria has reached an alarming level in many parts of the world, and treatment options against these bacteria have gradually become ineffective. Furthermore, as a result of the systematic evaluation of scientific data, it has been concluded that antimicrobial resistance has negative effects on the outcome of patients and the costs of healthcare services (23). Average of 700,000 deaths seen every year in European countries, and 1.5 billion dollars spent on treatment are thought to be caused by resistance of bacteria to antibiotics over time (7).

In fact, it is known that the resistance against antibiotics started before the widespread use of the substances included in this group throughout the world. However, this "first resistance" form against these substances did not pose a threat to animal and human health. On the other hand, most of the resistant microorganisms that are mentioned to pose a threat today have formed due to genetic changes, mutation and selection (9). While one of the factors that may increase the resistance of bacteria is the direct use of antibacterial drugs, another reason is the indirect contact of the drugs with the bacteria. In studies, resistance genes have been isolated from human pathogens, animal-derived bacteria and even environmental bacteria $(17,19,20)$.

Antibiotics are used for the treatment and control of various types of infections in many animal species as well as in humans. For this reason, resistance to antibiotics is a natural and inevitable situation. Multiple resistance cases occurring in factors that cause disease in humans have revealed the importance of the use of these substances both in the human and the veterinary medicine fields. Horses can be reservoir of antibiotic resistant organisms and genetic markers of resistance. This situation may affect animal welfare and the economy. This resistance may persist even in the absence of selection pressure (8).

Due to the close contact of humans and horses, the risks and consequences of human treatments and the application of common antimicrobial drugs used in horses is an issue that should be considered. It has been reported that common $E$. coli species in humans and animals show high resistance to common antimicrobial agents and there are antibiotic resistance genes such as dfrA17 and dfrA12
(12). These resistance genes are generally found on mobile genetic elements such as plasmids and integrons in Gramnegative microorganism isolates (3).

In this study, antibiotic susceptibility/resistance profile against the agents Streptococcus spp. and Staphylococcus spp. was determined in samples taken from thoroughbred British and Arabian horses brought to the 75. Y1l Hippodrome Hospital and due diligence has been made in this regard.

\section{Materials and Methods}

Tracheal aspiration fluid was collected by sampling method from a total of 133 thoroughbred horses, 93 thoroughbred British and 40 thoroughbred Arabian horses, aged 1 to 5 years old, registered in the studbook that are routinely brought to 75 . Yil Hippodrome Hospital between the dates of 24/04/2016 and 23/10/2017. Of these 93 British thoroughbred horses, 26 are female and 67 are male; out of 40 thoroughbred Arabian horses, 10 are female and 30 are male. The necessary Ethics Committee Approval was obtained from Ankara University Animal Experiments Local Ethics Committee for the study (Decision no: 2015-13-153).

The samples were brought to the Ankara University Department of Veterinary Medicine Pharmacology and Toxicology laboratory in the cold chain for bacterial isolation.

In the first isolation, 5\% Sheep Blood Agar (KA) was used. After inoculation, the growth cultures were incubated at $37^{\circ} \mathrm{C}$ for $24-48$ hours. After the incubation, colonies were purified in Tryptic Soy Agar (TSA) and stored at $-20^{\circ} \mathrm{C}$ in TSA containing $15 \%$ glycerin to be used for identification studies, antibiogram and MIC (Minimum Inhibitory Concentration) determination (4). Strains isolated and stored at $-20^{\circ} \mathrm{C}$ were reproduced for identification. Identification of bacteria was performed with Bruker Daltonik MALDI Biotyper (MALDI-TOF) (18).

Kirby-Bauer Disc Diffusion and Minimum Inhibitory Concentration (MIC) methods were used to determine the antibacterial resistance.

After incubation, inhibition zone diameters were measured in millimeters and standard zone diameters were compared with the standards specified by the "Clinical and Laboratory Standards Institute (CLSI)" and evaluated as "susceptible", "moderately susceptible" or "resistant" according to results. Each test was repeated three times to minimize the application errors that may occur at this stage, and the arithmetic mean of the obtained data was calculated.

The MIC value was determined by the microdilution method based on CLSI 2014. S. aureus ATCC 29213 standard strain was used as control strain (5). 
Table 1. Comparison table for susceptibility of 11 identified agents to antibiotics.

\begin{tabular}{|c|c|c|c|c|c|c|c|c|c|c|c|}
\hline Antibiotics & 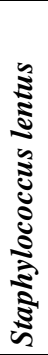 & 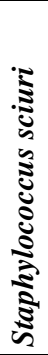 & 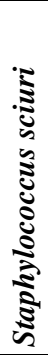 & 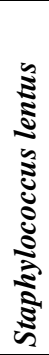 & 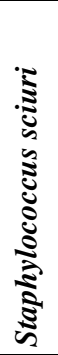 & 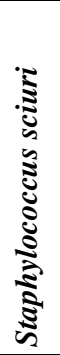 & 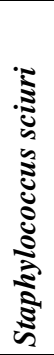 & 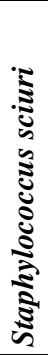 & 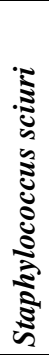 & 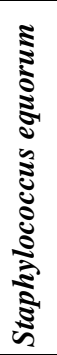 & 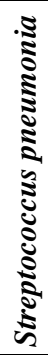 \\
\hline Amoxicilline (25) & $\mathrm{S}$ & $\mathrm{S}$ & $\mathrm{S}$ & $\mathrm{S}$ & $\mathrm{S}$ & $\mathrm{S}$ & $\mathrm{S}$ & $\mathrm{S}$ & $\mathrm{S}$ & $\mathrm{S}$ & $\mathrm{S}$ \\
\hline Penicillin G (10) & $\mathrm{R}$ & $\mathrm{R}$ & $\mathrm{R}$ & & & & & & & $\mathrm{S}$ & $\mathrm{S}$ \\
\hline TMPS (30) & & & $\mathrm{R}$ & I & $\mathrm{R}$ & $\mathrm{R}$ & $\mathrm{R}$ & $\mathrm{R}$ & $\mathrm{R}$ & $\mathrm{S}$ & $\mathrm{R}$ \\
\hline Canamycine (30) & $\mathrm{R}$ & $\mathrm{R}$ & & $\mathrm{R}$ & & & & & & I & \\
\hline Gentamicin (10) & $\mathrm{R}$ & $\mathrm{R}$ & & $\mathrm{R}$ & & & & & & $\mathrm{S}$ & \\
\hline Ampicillin-Sulbactam (20) & $\mathrm{S}$ & $\mathrm{S}$ & $\mathrm{S}$ & $\mathrm{S}$ & $\mathrm{S}$ & $\mathrm{R}$ & $\mathrm{S}$ & $\mathrm{S}$ & $\mathrm{S}$ & $\mathrm{S}$ & \\
\hline Amikacin (30) & & & & $\mathrm{R}$ & & & & & & $\mathrm{S}$ & \\
\hline Enrofloxacin (5) & $\mathrm{R}$ & $\mathrm{R}$ & $\mathrm{R}$ & $\mathrm{R}$ & $\mathrm{R}$ & $\mathrm{R}$ & $\mathrm{R}$ & $\mathrm{R}$ & $\mathrm{R}$ & $\mathrm{S}$ & \\
\hline Rifampin (5) & & $\mathrm{R}$ & I & & $\mathrm{R}$ & $\mathrm{R}$ & $\mathrm{R}$ & $\mathrm{R}$ & $\mathrm{R}$ & $\mathrm{S}$ & \\
\hline
\end{tabular}

S: Susceptible; I: Intermediate Susceptible; R: Resistance.

\section{Results}

Bacterial growth did not occur in 3 out of 133 samples. More than one bacteria was isolated from some samples. The isolated bacteria were primarily stained by the Gram staining method. After staining, Gram positive cocci shaped bacteria were separated. Possible separation of Streptococcus and Staphylococcus was performed by catalase testing. Colonies were stored at $-20^{\circ} \mathrm{C}$ for definitive identification, antibiogram, and MIC.

However; 4 Candida albicans, 155 Gram-negative bacteria, 2 Streptococcus spp. and 10 Staphylococcus spp. agents were determined. Streptococcus spp. and Staphylococcus spp. strains isolated from different horses were identified as following: 2 Staphylococcus lentus, 7 Staphylococcus sciuri, 1 Staphylococcus equorum and 1 Streptococcus pneumonia.

Susceptibility profiles of these strains against some penicillin, cephalosporin, aminoglycoside, tetracycline, rifamycin and carbapenem group antibacterial drugs [Amoxicillin, penicillin G, trimethoprim-sulfamethoxazole (TMPS), kanamycin, gentamicin, streptomycin, ampicillin-sulbactam, neomycin, amikacin, enrofloxacin, oxytetracycline, ceftiofur, ceftazidime, rifampin, imipenem and amoxicillin-clavulanic acid] were determined. Distribution of antimicrobial susceptibilities and antimicrobial resistance profiles of the strains were presented in Table 1.

It has been determined that agents are susceptible to amoxicillin and ampicillin-sulbactam; moderately susceptible to penicillin and amikacin; and resistant to trimethoprim-sulfamethoxazole, kanamycin, gentamicin, enrofloxacin and rifampin.

However, the susceptibility profile could not be revealed for streptomycin, neomycin, oxytetracycline, ceftiofur, ceftazidime, imipenem and amoxicillinclavulanic acid.

\section{Discussion and Conclusion}

There are not many studies on horse diseases, rational drug use and especially antibiotic resistance regarding thoroughbred horses with high economic value. One of the basic principles of rational treatment is to ensure the correct and effective drug use for diseases.

Mir et al. (21) conducted a study on the isolation and identification of aerobic bacteria in the upper respiratory tract of horses with 88 healthy heads and 53 heads with respiratory diseases in India. As a result of this study, $84.11 \%$ of the total 321 isolates isolated from both groups were found to be Gram-positive where as $15.88 \%$ of them were determined as Gram-negative bacteria. Among them, $17.44 \%$ of them were identified as Streptococcus equi subsp. Zooepidemicus and $9.65 \%$ of them were Corynebacterium. 9.65\% as Staphylococcus intermedius, $8.72 \%$ as Staphylococcus aureus, $7.16 \%$ as Bacillus spp., $5.60 \%$ as Streptococcus pneumonia, $5.60 \%$ as Staphylococcus chromogens, $5.29 \%$ as Streptococcus equismilis, $5.29 \%$ as Pseudomonas aeruginosa, $3.73 \%$ as Rhodococcus equi, $3.73 \%$ as Escherichia coli, $3.42 \%$ as Klebsiella pneumoniae, $3.42 \%$ as Proteus vulgaris and $1.24 \%$ as Streptococcus equi subsp. equi (21). 
In a study conducted by Gutema et al. (10) in Ethiopia, isolation and identification were performed in an aerobic environment by taking the swabs from the nasopharynx region of 80 healthy donkeys and also of 20 donkeys with respiratory diseases. In this study, a total of 189 bacteria species were identified from both groups. Among them, 159 of them (84.1\%) were gram positive and 30 of them are gram negative $(15.9 \%)$. Bacteria were detected at a higher rate in animals with respiratory diseases than in healthy ones (10).

In a study conducted by Johns and Adams (11), susceptibility for Escherichia coli isolated from the respiratory tract of horses from 1999 to 2012 was inspected. This research was divided into two groups as 242 isolates detected between 1999-2004 (early period) and 222 isolates detected between 2007-2012 (late period). Periodic comparison of the rates of each antimicrobial-resistant and multi-drug resistant isolates was made accordingly. There was a significant increase in the rate of ceftiofur $(\% 7.3-22.7 ; \mathrm{P}=0.002)$, gentamicin $(\% 28.5-53.9 ; \quad \mathrm{P}<0.001), \quad$ tetracycline $\quad(\% 48.4-74.2$, $\mathrm{P}=0.002)$ and MDR (\%26.6-49.4, $\mathrm{P}=0.007)$ of E. coli isolates. In all Streptococcus spp. $(S$. equi, $S$. zooepidemicus, S. equisimilis and unknown $\beta$-hemolytic Streptococcus spp. (UBHS)) enrofloxacin resistance increased considerably from the early period $(0 \%)$ to the late period $(63 \%)$ depending on the species. It was understood that tetracycline and MDR resistance of $\mathrm{S}$. zooepidemicus increased over time, trimethoprimsulfamethoxazole resistance decreased over time, and resistance against commonly used antibiotics in pathogenic agents of horses increased. Susceptibility to antibiotics was evaluated by the Kirby-Bauer disk diffusion method and zones according to the contemporary Clinical and Laboratory Standards Institute (CLSI) (previously, NCCLS) (11).

Darien et. al. (6) conducted a study on false reporting of the increase in trimethoprim-sulfamethoxazole resistance of $50 \mathrm{~S}$. equi isolates isolated from tracheal aspiration fluid taken from horses coming to Colorado State University Veterinary Training Hospital for both periods one of which is between the years 1987-1990 (1. Period) and the other is between the years 1997-2001 (2. Period). First, isolates tested in CSU-VDL (N 5 41) were analyzed by the Kirby-Bauer agar disc diffusion using Mueller-Hinton with 5\% sheep red blood cells as culture medium. Originally resistant isolates (N 5 7) in CSU-VDL were retested using Mueller - Hinton agar without adding blood. Isolates tested in Purdue (N 5 41) were analyzed by the Sensititre / Trek Broth Dilution method (using hemolyzed horse blood in Mueller-Hinton broth medium for testing with SXT). Considering the results obtained in this study, resistance development between the two periods was compared and statistically analyzed. It was understood that there were statistically significant differences between the results obtained by using the Quantitative Micro broth Dilution method in the period 1987-1990 (8\%) and the results obtained by using the Kirby-Bauer Agar Disc Diffusion method in the 19972001 period $(42 \%)$. This study revealed that even small deviations in the established laboratory test practice guidelines may have a major impact on antimicrobial resistance test results. The study underlines the need for appropriate surveillance and monitoring methods of trends in antimicrobial resistance to detect and correct such problems (6).

In a study conducted by Karilyn (13), antibiotic resistance of isolated bacterial colonies from the samples collected from the nasopharyngeal cavity of 27 horses in various farms in England was tested with the BBL Sensi Disc $^{\mathrm{TM}}$ antimicrobial resistance disc (Kirby Bauer antibiotic susceptibility test). Isolates obtained from $92.59 \%$ of the collected samples were Gram-positive coccus, $85.19 \%$ of them were Gram-negative coccus, $59.26 \%$ of them were Gram-negative bacilli and 25.93\% of them were Gram-positive bacilli. E. coli, Shigella spp, Enterobacter spp and $S$. aureus which are found in the natural nasopharyngeal flora of horses were also isolated.

Karilyn (13), 13 different antibiotic discs were used. These antibiotics were $30 \mu \mathrm{g}$ amikacin (AN), $10 \mu \mathrm{g}$ gentamicin (GM), $5 \mu \mathrm{g}$ ciprofloxacin (CIP), $30 \mu \mathrm{g}$ ceftriaxone (CRO), $2 \mu \mathrm{g}$ clindamycin (CC), $30 \mu \mathrm{g}$ cefotaxime (CTX), $10 \mu \mathrm{g}$ ampicillin (AM), $5 \mu \mathrm{g}$ chloramphenicol (C), $75 \mu \mathrm{g}$ ticarcillin (TIC), $25 \mu \mathrm{g}$ trimethoprim-sulfamethoxazole (SXT), $30 \mu \mathrm{g}$ tetracycline (Te), $10 \mu \mathrm{g}$ bacitracin (B) and $30 \mu \mathrm{g}$ vancomycin (Va).

According to the results obtained by measuring the zone diameters, $3.70 \%$ of isolates were susceptible to gentamicin, then $11.11 \%$ amikacin, $15.38 \%$ cefotaxime, $18.52 \%$ ciprofloxacin, $22.22 \%$ ceftriaxone, $28.00 \%$ clindamycin, $33.33 \%$ ticarcillin, $37.04 \%$ ampicillin, $44.44 \% \quad$ tetracycline, $44.44 \%$ trimethoprimsulfamethoxazole, $\quad 52.00 \%$ chloramphenicol, $62.96 \%$ vancomycin and $68.00 \%$ bacitracin respectively.

Amikacin, cefotaxime, ciprofloxacin and ceftriaxone were highly effective with values below $20 \%$ (Resistance values reflect the number of horses with antibiotic resistant bacteria compared to total sampled horses). Clindamycin, ampicillin, ticarcillin, trimethoprimsulfamethoxazole and tetracycline had a resistance value between $20 \%$ and $40 \%$. Chloramphenicol, vancomycin and bacitracin were relatively ineffective in killing normal horse flora at a rate of $50 \%$ to $70 \%$, and these antibiotics are not used much in the veterinary field (13).

Within the scope of this study, important results have emerged on the both a scientific and economic scale. In bacteria with resistance to antibiotics, the effectiveness of the drug and the benefit of the treatment may decrease. Evaluation of resistance is extremely important, especially for animal species and disease diversity. For this reason, 
countries have to do their own epidemiological studies. At this point, the results of the study reveal scientifically important data. The obtained data will also be a guide for veterinarians working in this field. It will be possible to choose antibiotics while creating treatment protocols in the field of veterinary medicine by considering these results.

In case of resistance, diseases that transmitted from animal to animal or from animal to human will become widespread. This situation is also important in terms of public health. Since the effectiveness of the drugs against resistant bacteria will decrease, they will be used with increasing doses.

Identifying the development of resistance to some commonly used drugs in veterinary medicine may help to find out the resistant strains in humans as well. Thus, this study may have a relevant importance in providing some data on the strains having a porentail to develop resistance against antibiotics in humans.

\section{Acknowledgements}

This research study is produced from a doctoral- $\mathrm{PhD}$ thesis.

\section{Financial Support}

This research study was funded by Scientific Research Project Coordination Unit of Ankara University, (Grant number: 16L0239011).

\section{Ethical Statement}

Ethics committee approval of Ankara University Animal Experiments Local Committee was received for this research study (Approval No: 2015-13-153).

\section{Conflict of Interest}

The authors declare that they have no conflict of interest.

\section{References}

1. Acet A (1989): Hayvansal gıdalarda antimikrobiyal ilaç rezidüleri. Türk Veteriner Hekimliği Derg, 3, 32-36.

2. Akkan HA, Karaca M (2003): Veteriner İç Hastalıklarında Antibiyotik Kullanımı. Yüzüncü Y1l Üniversitesi Veteriner Fakültesi Derg, 14, 72-77.

3. Alekshun MN, Levy SB (2007): Molecular mechanisms of antibacterial multidrug resistance. Cell, 28, 1037-1050.

4. Boyle AG, Timoney JF, Newton JR, et al (2018): Streptococcus equi Infections in Horses: Guidelines for Treatment, Control, and Prevention of Strangles-Revised Consensus Statement. J Vet Intern Med, 32, 633-647.

5. CLSI (2014): Performance Standards for Antimicrobial Susceptibility Testing; Twenty-Fourth Informational Supplement. CLSI Document M100-S24, Wayne, 34.

6. Darien JF, Doreene H, Josie TD, et al (2005): Investigation of falsely reported resistance of Streptococcus equi subsp. zooepidemicus isolates from horses to trimethoprim-sulfamethoxazole. J Vet Diagn Invest, 17, 483-486.

7. ECDC, EFSA, EMA (2017): Joint Scientific Opinion on a list of outcome indicators as regards surveillance of antimicrobial resistance and antimicrobial consumption in humans and food-producing animals. Available at file://C:/Users/HP/Downloads/2017-

EFSA_Journal\%20(1).pdf. (Accessed February 18, 2018).

8. FVE (2007): Antibiotic resistance \& prudent use of antibiotics in veterinary medicine. Published by Federation of Veterinarians of Europe.

9. FVE (2018): Antibiotic resistance and prudent use of antibiotics in veterinary medicine. Available at http://www.fve.org/news/publications/pdf/antibioen.pdf. (Accessed February 17, 2017).

10. Gutema DF, Duguma BE, Dinka AG (2007): Isolation and identification of aerobic bacretial flora from the upper respiratory tract of donkeys in Central Ethiopia. Faculty of veterinary medicine of Addis Ababa University Donkey Health and Welfare Project.

11. Johns IC, Adams EL (2015): Trends in antimicrobial resistance in equine bacterial isolates. 1999-2012. Veterinary Record, 176, 334.

12. Kang HY, Jeong YS, Oh JY, et al (2005): Characterization of antimicrobial resistance and class 1 integrons found in Escherichia coli isolates from humans and animals in Korea. J Antimicrob Chemother, 55, 639-644.

13. Karilyn A (2004): Equine infectious disease and microbial resistance to antibiotics. Dartmouth Undergraduate Journal of Science. Spring.

14. Kaya S (1984): Hayvansal üretimde gelişmeyi hızlandırıcı maddeler ve sakıncalart. Ankara Univ Vet Fak Derg, 31, 410-423.

15. Kaya S, Şahal M (1989): Besinlerimizdeki ilaç kalıntıları, bunlara ilişkin tolerans düzeyleri, ilaç verilmiş hayvanlarda uyulması gereken kesim öncesi bekletme veya sütün kullanılmama süreleri. Ankara Univ Vet Fak Derg, 36, 390403.

16. Kaya S, Yavuz HBC, Akar F, et al (1993): Mezbahadan sağlanan sığır et, karaciğer ve böbrek örneklerinde antibiyotik kalıntıları. Ankara Univ Vet Fak Derg, 39, 13-29.

17. Kemper N (2008): Veterinary antibiotics in the aquatic and terrestrial environment. Ecological Indicators, 8, 1-13.

18. Mani RJ, Thachil AJ, Ramachandran A (2017): Discrimination of Streptococcus equi subsp. equi and Streptococcus equi subsp. zooepidemicus using matrixassisted laser desorption/ionization time-of-flight mass spectrometry. J Vet Diagn Invest, 29, 622-627.

19. Martinez JL (2009): Environmental pollution by antibiotics and by antibiotic resistance determinants. Environmental Pollution, 157, 2893-2902.

20. Martinez M, Silley P (2010): Antimicrobial Drug Resistance. Handb Exp, 199, 227-264.

21. Mir IA, Kumar B, Taku A, et al (2013): The study of aerobic bacterial flora of the upper respiratory tract of equines from Jammu and Kashmir region of India. Veterinary World, E-ISSN: 2231-0916.

22. Sağmanligil H (1989): Antibiyorezistans oluşumu ve sağhlk yönünden getirdiği sorunlar. U Ü Vet Fak Derg, 8-9, 249-256.

23. WHO (2014): Antimicrobial resistance: Global report on surveillance. Edited by World Health Organization. 